\title{
MAREK SoBczyK
}

Uniwersytet Mikołaja Kopernika

\section{POJECCIE 'CAUSA' W ŹRÓDŁACH PRAWA RZYMSKIEGO ODNOSZĄCYCH SIE DO BEZPODSTAWNEGO WZBOGACENIA}

\section{Problem BadAWCZy}

Definiując termin causa w słowniku encyklopedycznym prawa rzymskiego Adolf Berger stwierdził, że jest to jeden z najbardziej niejasnych terminów rzymskiego języka prawniczego ${ }^{1}$. Obserwacji tej trudno odmówić racji, zwłaszcza jeśli weźmie się pod uwagę różnorodność sytuacji, w których prawnicy rzymscy posługiwali się tym terminem. Wieloznaczność tego pojęcia jest podkreślana w każdym z opracowań jemu poświęconych ${ }^{2}$. Janusz Sondel wyróżnił aż dwadzieścia siedem znaczeń tego terminu³. Wśród najczęściej wskazywanych znaczeń causa w romanistyce podaje się: przyczynę, powód; podstawę; cel; pobudke, motyw; stosunek prawny, interes, transakcję;

1 A. Berger, Encyclopedic Dictionary of Roman Law, Philadelphia 1953, s.v. causa.

2 A. Söllner, Die causa im Kondiktionen - und Vertragsrecht des Mittelalters bei den Glossatoren, Kommentatoren und Kanonisten, «ZSS»77/1960, s. 189; T. DALLA-Massara, Sul responsum di Aristone in D.2.14.7.2 (Ulp. 4 ad ed.): l'elaborazione del concetto di causa del contratto, [w:] Le dottrine del contratto nella giurisprudenza romana, red. A. Burdese, Milano 2006, s. 303 i n.; M. PentA, La causa come elemento negoziale nel diritto romano, [w:] Rivista di Scuola superiore dell'economia e delle finanze 2010, s. 7.

3 J. Sondel, Słownik tacińsko-polski dla prawników i historyków, Kraków 2005, s.v. causa. 
położenie, stan; sprawe, przedmiot: kroki prawne, proces; istotę treść, znaczenie, pojęcie ${ }^{4}$. Słusznie zatem zauważył Fritz Schwarz, że posługując się pojęciem causa należy wskazywać kontekst, w którym zostaje ono użyte 5 .

Mimo różnorodności zastosowania tego terminu da się wyróżnić pewne instytucje prawne, w których termin ten uzyskiwał szczególne znaczenie, dotyczy to zwłaszcza:

a) causa rozumianej jako przyczyna, ze względu na którą następuje przeniesienie własności res nec mancipi poprzez wydanie (causa traditionis);

b) causa rozumianej jako przesłanka nabycia własności rzeczy poprzez zasiedzenie (causa usucapionis);

c) causa rozumianej jako podstawa nabycia posiadania (causa possessionis);

d) causa rozumianej jako przesłanka społeczno - gospodarcza, której służy dany kontrakt;

e) causa jako podstawa przyrzeczenia stypulacyjnego (causa stipulationis);

f) causa jako przesłanka warunkująca zaskarżalność kontraktu nienazwanego.

Kolejnym obszarem prawnym, w ramach którego pojęcie causa było częściej wykorzystywane jest obszar nazywany według nomenklatury współczesnej bezpodstawnym wzbogaceniem ${ }^{6}$. W literaturze romanistycznej zagadnienie causa opracowywano przede wszystkim

${ }^{4}$ Por. znaczenia podane w 'Vocabularium Iurisprudentiae Romanae', Berlin 1903, I, s.v. causa; H. Heumann, E. SecKel, Handlexikon zu den Quellen des römischen Rechts, Jena 1914, s.v. causa. J. Sondel, op. cit., s.v. causa. Zob. również znaczenia causa wskazywane przez F. Schwarza, Die Grundlage der 'condictio' im klassischen römischen Recht, Münster-Köln 1952, s. 120 i n.; S. HÄHNCHEN, Die 'causa condictionis'. Ein Beitrag zum klassischen römischen kondiktionenrecht, Berlin 2003, s. 17.

5 F. SchwARZ, op. cit., s. 221.

${ }^{6}$ Współczesne prawo polskie posługuje się terminem,,bezpodstawne wzbogacenie” w miejsce dawniej używanego terminu „niesłuszne wzbogacenie”. Zmiana terminologii nie ma charakteru wyłącznie formalnego, lecz jest refleksem dyskusji na temat fundamentów tej instytucji prawnej, a zwłaszcza na temat roli słuszności jako podstawy roszczenia o zwrot wzbogacenia. Szerzej na ten temat pisałem w artykule pt. 
W odniesieniu do systemu kontraktowego ${ }^{7}$, przeniesienia własności poprzez traditio ${ }^{8}$ i kontraktu stypulacji ${ }^{9}$, a ilość prac poświęconych tym zagadnieniom jest ogromna. Znacznie mniejszym zainteresowaniem zagadnienie to cieszy się w pracach dotyczących bezpodstawnego wzbogacenia ${ }^{10}$. Z tego względu postanowiłem prześledzić znaczenie w jakim termin causa został użyty w tytułach czwartym, piątym, szóstym i siódmym dwunastej księgi Digestów, poświęconych odpowiednio następującym figurom condictiones: condictio causa data causa non secuta, condictio ob turpem vel iniustam causam, condictio indebiti, condictio sine causa. Wskazane źródła nie wyczerpują problematyki bezpodstawnego wzbogacenia w prawie rzymskim, choć są z pewnością najistotniejsze. Dodaję jednak, ze względu na ograniczone ramy niniejszego opracowania nawet w ramach wymienionych tytułów dwunastej księgi Digestów dokonuję analizy w mojej ocenie najważniejszych, choć nie wszystkich fragmentów, w których pojawia się termin causa.

Zasadniczym celem niniejszego opracowania nie jest samo li tylko wykazywanie znaczeń causa w źródłach dotyczących bezpodstawnego wzbogacenia. Celem tym jest próba udziału w dyskusji na szeroko ostatnio podejmowany temat rzymskiej koncepcji bezpodstawnego wzbogacenia, a w szerszym kontekście aktualnie cieszącej się dużym

The problem of 'causa condictionis' in the settlements of Roman jurists and in modern Polish unjustified enrichment law, «Studia Prawnoustrojowe» 9/2009, s. 29-42.

7 Zob. ostatnio prace opublikowane w publikacjach zbiorowych pt. 'Causa' e contratto nella prospettiva storico-comparatistica (Palermo, 7-8 giugno 1995), red. L. VACCA, Torino 1997 i Le dottrine del contratto nella giurisprudenza romana, red. A. Burdese, Milano 2006; T. Dalla-Massara, Alle origini della causa del contratto. Elaborazione di un concetto nella giurisprudenza classica, Padova 2004; M.J. Golecki, 'Synallagma'. Filozoficzne podstawy odpowiedzialności kontraktowej w klasycznym prawie rzymskim, Torun 2008, s. 204 i n.

${ }^{8}$ Zob. ostatnio na ten temat L. Labruna, 'Tradere' ed altri studi, Napoli 1998, s. 20; O. Behrends, 'Iusta causa traditionis', [w:] L. Labruna, 'Tradere'..., s. 27 i n.

9 Zob. monografię J. G. Wolf, 'Causa stipulationis', Köln-Wien 1970.

10 Szerzej tę problematykę podjął S. E. Wunner, Der Begriff 'causa' und der Tatbestand der 'condictio indebiti', «Romanitas» 9/1970, s. 459-483. Najczęściej jednak w pracach poświęconych bezpodstawnemu wzbogaceniu pojęcie causa nie stanowi głównego wątku rozważań i zwykle też nie jest głębiej analizowane. 
zainteresowaniem problematyki bezpodstawnego wzbogacenia i restytucji w ujęciu historycznym i prawnoporównawczym. Dość wspomnieć, że w samej romanistyce ukazało się ostatnio kilka prac dość gruntownie podważających dotychczas przeważające poglądy. Mam tu na myśli ostatnie prace poświęcone tzw. causa condictionis, tj. wspólnej wszystkim condictiones podstawie skargi, odrzucające zarówno teorię słuszności, jak i niżej opisaną koncepcję causa retinendi ${ }^{11}$, prace stawiające w centrum rzymskiej koncepcji bezpodstawnego wzbogacenia datio sine causa ${ }^{12}$ i prace odrzucające tradycyjny pogląd, że konieczną przesłanką zastosowania condictio było uzyskanie wzbogacenia wskutek świadczenia polegającego na przeniesieniu własności $(\text { dare })^{13}$. W pracach tych dokonywano analizy również tych źródeł, w których pojawia się termin causa, jednakże wyciagane z tych źródeł wnioski często nie są przekonujące, co wynika m.in. z braku głębszej refleksji nad zagadnieniem causa. Z tych względów postanowiłem poddać analizie relewantne źródła jedynie pod kątem tego w jakim znaczeniu oraz $\mathrm{w}$ jakim kontekście sytuacyjnym użyto w nich terminu causa. Uważam bowiem, że analiza taka może okazać się użyteczna w kontekście innych problemów badawczych podejmowanych w nauce.

\section{PoszcZególne ZNACZENIA CAUSA}

1. Causa określająca istnienie stanu, w którym pewne dobro majątkowe znajduje się u innej osoby

W pierwszym rzędzie na uwagę zasługują te rozstrzygnięcia jurystów, w których termin causa odnosi się do stanu faktycznego, w któ-

11 S. HÄHNCHEN, op. cit., passim; N. JANSEN, Die Korrektur grundloser Vermögensverchiebungen als Restitution? Zur Lehre von der ungerechtfertigten Bereicherung bei Savigny, «ZSS»120/2003, s. 106-182.

12 J. D. Harke, Das klassische römische Kondiktionensystem, «Iura» 54/2003, s. 49-86; TENŻE, Römisches Recht, München 2008, s. 184.

13 A SAccoccio, 'Si certum petetur'. Dalla 'condictio' dei 'veteres' alle 'condictiones' giustinanee, Milano 2002; S. HeINE, 'Condictio sine datione'. Zur Haftung aus ungerechtfertigter Bereicherung im klassischen römischen Recht und zur Entstehung des Bereicherungsrechts im BGB, Berlin 2005. 
rym pewne dobro majątkowe, w szczególności pieniądz lub rzecz, przynależne jednej osobie znajduje się u innej osoby. Tym rozumieniem pojęcia causa posługiwali się już najstarsi juryści, co poświadcza Ulpian w osiemnastej księdze komentarza do dzieł Sabinusa:

\section{12,5,6 (Ulp. 18 ad Sab.): Perpetuo Sabinus probavit veterum opinionem existimantium id, quod ex iniusta causa apud aliquem sit, posse condici: in qua sentetia etiam Celsus est.}

Ulpian przytacza tutaj opinię veteres zaaprobowaną przez działającego w I poł. I w. n.e. Masuriusa Sabinusa ${ }^{14}$, a w II n.e. także przez Publiusa Iuventiusa Celsusa ${ }^{15}$, zgodnie z którą można żąać zwrotu tego, co znajduje się u innej osoby z niesłusznej przyczyny (ex iniusta causa). Mianem veteres określano jurystów okresu prawa przedklasycznego ${ }^{16}$. Przytoczona opinia veteres ma charakter bardzo ogólny, stanowi wyraz pewnej zasady, która w swej treści nie odnosi się do żadnej konkretnej sytuacji ani też nie wzmiankuje żadnej konkretnej figury condictio ${ }^{17}$, nie da się też w sposób pewny ustalić kontekstu w jakim zasadę tę przywołał Ulpian ${ }^{18}$. Termin causa służy tutaj określeniu stanu faktycznego, w którym określone dobro majątkowe znajduje się u innej osoby. Jeżeli causa istniejącego stanu rzeczy jest iniusta,

${ }^{14} \mathrm{Na}$ temat Masuriusa Sabinusa zob. W. Kunkel, Herkunft und Soziale Stellung der römischen Juristen, Graz-Wien-Köln 1967, s. 119 i n.; W. BOJARSKI, W. DAJCZAK, A. SoKala, 'Verba iuris'. Reguly i kazusy prawa rzymskiego, Toruń 2007, s. 140.

${ }^{15} \mathrm{Na}$ temat Publiusa Iuventiusa Celsusa zob. W. Kunkel, op. cit., s. 146 i n.; W. Bojarski, W. DajczaK, A. Sokala, op. cit., s. 134 i n.

${ }^{16}$ Szerzej zob. F. HoraK, Wer waren die 'veteres'. Zur Teminologie der klassischen römischen Juristen, [w:] 'Vestigalia Iuris Romani'. Festschrift für G. Wesener zum 60. Geburtstag am 3. Juni 1992, red. G. KLingenberg, J.M. Rainer, H. Stiegler, Graz 1992, s. 201 i n.; A. SACCOCCIO, op. cit., s. 98 i n.

${ }^{17} \mathrm{~W}$ okresie procesu formułkowego condictio pozostawała jednolitą skargą, najwcześniej dopiero w prawie późnoklasycznym zaczęto wyróżniać poszczególne typy sytuacji (postaci dationes), w których tą skargą się posługiwano, co nie wpłynęło jednak na jednolity charakter skargi. Nomenklatura użyta w tytułach dwunastej księgi Digestów pochodzi prawdopodobnie dopiero od kompilatorów.

18 Por. S.E. WunNer, op. cit., s. 476. Na różnorodność sytuacji, w których Ulpian mógł przywołać cytowaną zasadę wskazuje S. HäHNCHEN, op. cit., s. 67 i n. 
uprawniony ma prawo żądać zwrotu tego dobra majątkowego posługując się skargą nazywaną condictio ${ }^{19}$. Ulpian nie podaje jaką postać ma dobro majątkowe posługując się bardzo ogólnym zaimkiem id, nie wskazuje też kiedy causa ma charakter iniusta, w szczególności nie odnosi się do tego, w jaki sposób dobro majątkowe znalazło się u innej osoby oraz czy stan taki istniał począwszy od chwili uzyskania dobra, czy zaistniał później. Wydaje się wszakże, że istotne jest nie tyle to, w jaki sposób dobro znalazło się u innej osoby, ale to czy znajduje się u niej ex iniusta causa.

Causa została opisana od strony negatywnej jako iniusta, co oznacza, że roszczenie o zwrot korzyści majątkowej nie ma podstaw prawnych nie tylko wtedy kiedy coś znajduje się u innej osoby ze słusznej podstawy, ale także wtedy kiedy osoba występująca z żądaniem zwrotu nie wykazała, że podstawa istniejącego stanu rzeczy jest niesłuszna. Treść fragmentu nie pozwala na jednoznaczną i pewną ocenę, czy uprawniony mógł posłużyć się condictio tylko wtedy kiedy osoba, u której znajduje się dobro majątkowe nabyła jego własność wskutek świadczenia polegającego na dare, czy też również wtedy kiedy nie nastąpiło przeniesienie własności albo jej nabycie w inny sposób, a zatem czy stan apud aliquem sit obejmuje także posiadanie lub nawet detencję rzeczy. W świetle tradycyjnego poglądu condictio była stosowana jedynie w przypadku, kiedy pozwany nabył własność żądanej rzeczy w szczególności wskutek świadczenia polegającego na dare, a zatem sformułowanie apud aliquem sit odnosiłoby się jedynie do tych sytuacji, w których pozwany stał się właścicielem danego dobra majątkowego ${ }^{20}$, w pozostałych przypadkach uprawniony mógłby posłużyć się rei vindicatio. Przy przyjęciu tego stanowiska uwydatnia się różnica między rozumieniem pojęcia causa w cytowanym poglądzie veteres i rozumieniem causa jako przesłanki nabycia własności

${ }^{19}$ L. VAcCA, Osservazioni in tema di 'condictio' e "arricchimento senza causa" nel diritto romano classico, [w:] L'arricchimento senza causa. Atti del convegno dell'Università degli Studi Roma Tre, Roma 24 e 25 ottobre 2003, s. 11 i n., uzasadnia pogląd veteres tym, że kierowali się oni zasadą słuszności, czego dowodem ma być fragment ósmej księgi Pytań Papiniana (D. 12,6,66).

${ }^{20}$ L. VACCA, op. cit., s. 12. 
res nec mancipi poprzez traditio ${ }^{21}$. Przeniesienie własności rzeczy poprzez traditio wymagało iusta causa traditionis, tj. słusznej podstawy przeniesienia własności, jeżeli zaś podstawa ta nie była słuszna (causa iniusta) do przeniesienia nie dochodziło ${ }^{22}$. W powyższym przypadku zatem, gdyby odnieść iniusta causa do causa traditionis okazałoby się, że osoba, u której znajduje się rzecz nie jest jej właścicielem, w związku z czym uprawniony powinien posłużyć się rei vindicatio, a jeśli wydanie rzeczy okazałoby się niemożliwe condictio $^{23}$. W konsekwencji opowiadając się za poglądem tradycyjnym wiążącym condictio z uprzednią datio należałoby przyjąć interpretację, że czym innym jest causa traditionis, która w tym przypadku była zachowana prowadząc do skutecznego przeniesienia własności i czym innym jest causa uzasadniająca żąananie zwrotu dobra majątkowego ${ }^{24}$.

Opisany wyżej pogląd tradycyjny został ostatnio poddany krytyce, jako bezpodstawny ${ }^{25}$. Zwolennicy nowego poglądu postawili hipotezę, że w czasach veteres żądanie zwrotu dobra majątkowego nie ograniczało się do sytuacji, w której dobro to znalazło się w cudzym majątku wskutek przeniesienia jej własności, wystarczyło bowiem, aby trafiła do tego majątku w jakikolwiek sposób, byleby tylko zaistniał stan definiowany zwrotem ex iniusta causa ${ }^{26}$. Według tego poglądu określenie

${ }^{21} \mathrm{Na}$ temat tego rozróżnienia zob. B. KupIsch, Ungerechfertigte Bereicherung. Geschichtliche Entwicklungen, Heidelberg 1987, s. 9 i n.; L. VACCA, op. cit., s. 18 i n. Sceptyczną postawę wobec tego rozróżnienia zajął ostatnio J. D. Harke, Das klassische römische Kondiktionensystem..., s. 52, ktorego zdaniem brak causa oznacza brak causa traditionis. Pogląd ten jest możliwy do obrony tylko przy założeniu, że zastosowanie condictio nie wymagało uprzedniej datio.

22 C. A. CAnnata, Materiali per un corso di fondamenti del diritto europeo, Torino 2005, s. 95.

${ }^{23}$ Pomijam w tym miejscu dyskusyjny problem dopuszczalności zbiegu rei vindicatio i condictio. Poglądy romanistyki na ten temat przedstawia W. PIKA, 'Ex causa furtiva condicere' im klassischen römischen Recht, Berlin 1998, s. 109 i n.

${ }^{24}$ Por. L. VACCA, op. cit., s. 22 i n.

${ }^{25}$ Mam tu na myśli prace A. SACCoccio, op. cit., passim i S. HeIne, op. cit., passim.

${ }^{26}$ D. Liebs, The Roman 'Condictio' up to Justinian, [w:] The Legal Mind. Essays for Tony Honoré, red. N. MacCormick, P. Birks, Oxfrod 1986, s. 174; L. Pellecchi, 
apud aliquem sit nie ogranicza się zatem do prawa własności, przeciwnie, jego ogólna formuła zdaje się nie przywiązywać znaczenia do tego, czy osoba, u której jest rzecz ma do niej jakiekolwiek prawo rzeczowe bądź obligacyjne. Aprobata tego punktu widzenia prowadzi do wniosku, że odróżnianie znaczenia w jakim został użyty termin causa w analizowanym źródle od causa traditionis zatraca swą istotność, albowiem w ogóle przestaje być istotne to, czy przedmiot wzbogacenia stał się własnością wzbogaconego.

Podobną ogólną wypowiedź sformułował Marcianus w trzeciej księdze Reguł:

D. 25,2,25 (Marc. 3 reg.): Rerum quidem amotarum iudicium sic habet locum, si divortii consilio res amotae fuerint et secutum divortium fuerit. sed si in matrimonio uxor marito res subtraxerit, licet cessat rerum amotarum actio, tamen ipsas res maritus condicere potest: nam iure gentium condici puto posse res ab his, qui non ex iusta causa possident.

Marcianus odnosi się do przypadku kradzieży przez żonę rzeczy stanowiącej własność męża. Jeżeli kradzieży takiej dokonano w celu uzyskania rozwodu (divortii consilio) i rozwód ten rzeczywiście miał miejsce, poszkodowanemu przysługuje actio rerum amotarum ${ }^{27}$. Ze względu bowiem na potrzebę ochrony małżeństwa kradzież taka nie była objęta rzymskim furtum, w związku z czym okradziony małżonek nie mógł skorzystać z actio furti ${ }^{28}$. Jeżeli jednak żona ukradła rzecz męża w czasie trwania małżeństwa i małżeństwo to nadal trwa, mężowi nie przysługuje actio rerum amotarum, lecz może posłużyć się

L'azione di ripetizione e le qualificazioni del dare in Paul. 17 ad Plaut. D.12.6.65 contributo allo studio della 'condictio', «SDHI» 4/1998, s. 81 i n.; A. SACCOCCIO, op. cit., s. 103 i n.; J. D. Harke, Das klassische römische Kondiktionensystem..., s. 51 i n.

${ }^{27}$ Podobnie przesłanki zastosowania tej skargi opisuje Paulus w siódmej księdze komentarza do dzieł Sabinusa (D. 25,2,1).

${ }^{28}$ Szerzej na temat actio rerum amotarum zob. W. PIKA, op. cit., s. 79 i n. wraz $\mathrm{z}$ literaturą tam przywoływaną. 
condictio $\mathrm{w}$ celu odzyskania skradzionej rzeczy ${ }^{29}$. Uzasadnieniem tego rozstrzygnięcia jest stwierdzenie, że zgodnie z ius gentium można żądać zwrotu rzeczy od tych osób, które posiadają je bez słusznej podstawy (non ex iusta causa). W opisywanym przypadku znaczenie ma nie tylko fakt posiadania bez słusznej podstawy, ale i naruszenie prawa, wskutek którego kobieta uzyskała posiadanie. Żona, która ukradła rzecz z oczywistych względów nie nabyła jej własności, stała się jedynie posiadaczem tej rzeczy, zaś jej posiadanie nie jest oparte na prawidłowej podstawie prawnej, stąd mąż może pozwać ją o zwrot tej rzeczy. Termin causa odnosi się zatem do podstawy posiadania korzyści majątkowej, którą posiadacz nabył wskutek kradzieży. Uzyskanie posiadania rzeczy w inny sposób niż wskutek datio nie stało na przeszkodzie posłużeniu się condictio, co jednak da się wyjaśnić szczególnym charakterem condictio ex causa furtiva wśród condictiones, nie ma bowiem wątpliwości co do tego, że w przypadku kradzieży wymógł nabycia rzeczy wskutek datio z oczywistych względów nie mógł mieć zastosowania.

Cytowany przez Paulusa w siódmej księdze komentarza do dzieł Sabinusa opisuje w podobny sposób taki sam przypadek:

\section{25,2,6,5 (Paul. 7 ad Sab.): Aristo et condici ei posse recte putat, quia ex iniusta causa apud eam essent.}

Paulus odnosząc się do popełnionej przez żonę kradzieży rzeczy męża przytacza pogląd prawny Aristona, zgodnie z którym można żądać zwrotu tej rzeczy, ponieważ jest ona u żony bez słusznej podstawy. W tym przypadku causa odnosi się do posiadania skradzionej rzeczy. Uważam, że pojęcie to można odnieść zarówno do podstawy posiadania jak i tytułu posiadania (sposobu w jaki posiadanie zostało nabyte), określa ono bowiem prawidłowość istniejącego stanu faktycznego, w którym rzecz wskutek kradzieży znalazła się u żony. Tego znacze-

29 Zdaniem S. HÄHNCHEN, op. cit., s. 65, nie może to być condictio ex causa furtiva, ponieważ furtum nie mogło zaistnieć między małżonkami. W. PIKA, op. cit., s. 82, zasadnie zauważa jednak, że skargą tą była po prostu condictio, ponieważ w epoce prawa klasycznego była to skarga jednolita, wobec czego nie opatrywano jej dopiskiem ex causa furtiva. 
nia causa nie można już odnieść do causa traditionis, skoro traditio w ogóle nie miała miejsca. Rozstrzygnięcia dotyczące kradzieży rzeczy przez małżonka mogą stanowić argument na rzecz tezy, że także i w pierwszym z analizowanych źródeł (D. 12,5,6) sformułowanie ex iniusta causa nie odnosi się jedynie do przypadków świadczeń polegających na przeniesieniu własności.

Także jurysta późnoklasyczny Papinian w ósmej księdze Pytań posłużył się podobnie rozumianą causa:

D. 12,6,66 (Papin. 8 quaest.): Heac condictio ex bono et aequo introducta, quod alterius apud alterum sine causa deprehenditur, revocare consuevit.

Według słów Papiniana ta condictio, wprowadzona ze względu na to, co dobre i słuszne, służy odzyskaniu tego, co z majątku jednego znajduje się bez podstawy w majątku drugiego ${ }^{30}$. Wypowiedź Papiniana przypomina cytowany wyżej pogląd prawny veteres i stanowi interesujące źródło dodatkowo o tyle, że łączy condictio z zasadą słuszności, co może stanowić argument za tym, że słuszność była podstawą roszczenia $\mathrm{z}$ tytułu bezpodstawnego wzbogacenia ${ }^{31}$. Termin sine cau$s a$ odnosi się tu do faktu, że jakaś korzyść majątkowa bliżej nieopisana znajduje się u innej osoby. Wypowiedź ta ma charakter bardzo ogólny i nie odnosi się do żadnej konkretnej sytuacji, z tego względu także stanowi argument za tym, że przesłanką zastosowania condictio nie musi być uprzednia datio.

2. Causa odnosząca się do podstawy prawnej uzyskania korzyści majątkowej

W innym znaczeniu terminem causa posłużył się Papinian w drugiej księdze Pytań:

${ }^{30}$ W ocenie L. VACCA, op. cit., s. 11 i n., fragment ten uzasadnia stwierdzenie, że podstawą roszczenia o zwrot korzyści majątkowej była słuszność.

31 Pogląd taki odrzucili jednak ostatnio S. HäHnCHEN, op. cit., s. 91 i n. i J. D. HARKe, Das klassische römische Kondiktionensystem..., s. 60 przyp. 26. 
D. 12,6,54 (Pap. 2 quaest.): Ex his omnibus causis, quae iure non valuerunt vel non habuerunt effectum, secuta per errorem solutione condictioni locus erit.

Wypowiedź Papiniana zawiera ogólne określenie tych sytuacji, w których zastosowanie znajduje condictio indebiti, mianowicie skargą tą można posłużyć się we wszystkich tych stosunkach prawnych, które były prawnie nieważne lub nie odniosły skutku prawnego, a świadczenie zostało spełnione pod wpływem błędu.

Dopełnienie rzeczownika causae sformułowaniem quae iure non valuerunt vel non habuerunt effectum przesądza o tym, że termin ten nie służy ogólnemu określeniu ,przypadku” lub „,sytuacji” bądź „przyczyny”, lecz określa relację stron, z której mają wynikać skutki prawne. Z całości fragmentu wynika, że chodzi tu o stosunki prawne zobowiązujące ich stronę do świadczenia. Jeżeli takie zobowiązanie było z jakiś przyczyn nieważne lub nie odniosło skutku prawnego, a zatem obiektywnie nie istniało, a mimo to świadczący wykonał je po wpływem błędu, że jest do tego obowiązany, może żądać zwrotu swego świadczenia. Papinian nie wskazuje tu źródeł zobowiązania, choć najistotniejsze znaczenie mają tu zobowiązania wynikające z kontraktów. Causa oznacza tutaj zatem podstawę prawną obowiązku świadczenia, a w konsekwencji odnosi się do podstawy prawnej uzyskania korzyści majątkowej.

W podobnym znaczeniu Ulpian posłużył się terminem causa w 43 księdze komentarza do dzieł Sabinusa, także zamieszczonym w tytule poświęconym condictio indebiti:

D. 12,6,23,4 (Ulp. 43 ad Sab.): Si qua lex ab initio dupli vel quadrupli statuit actionem, dicendum est solutum ex falsa eius causa repeti posse.

Jeżeli ustawa przewiduje od początku skargę o podwójną lub o poczwórną wartość, to to, co zostało świadczone w fałszywym przekonaniu, że spełniły się przesłanki ustawy, podlega zwrotowi. W tym przypadku causa odnosi się do opisanych w ustawie przesłanek świad- 
czenia, jeżeli causa okazuje się falsa, a zatem przesłanki te w rzeczywistości nie zachodzą, można żądać zwrotu świadczenia.

3. Causa odnosząca się do sposobu nabycia korzyści majątkowej

W nieco innym znaczeniu Ulpian posłużył się terminem causa w innym fragmencie 43 księgi komentarza do dzieł Sabinusa:

D. 12,7,1,3 (Ulp. 43 ad Sab.): Constat id demum posse condici alicui, quod vel non ex iusta causa ad eum pervenit vel redit ad non iustam causam.

Według słów Ulpiana można żądać zwrotu od innej osoby tego, co albo trafiło do niej nie ze słusznej przyczyny albo powraca do przyczyny, która nie jest słuszna.

Tym razem termin causa nie odnosi się do stanu faktycznego, lecz do sposobu, w jaki inna osoba uzyskała korzyść majątkową. Użycie czasownika pervenire oznaczającego m. in. przybyć dokadś, dostać się; dojść do czegoś, uzyskać, dopiać czegoś; przypaść komuśs ${ }^{32}$, oznacza, że causa nie odnosi się do elementu statycznego pozostawania korzyści u innej osoby, lecz do zdarzenia, mogącego nawet przybrać postać procesu, którego skutkiem jest to, że korzyść majątkowa znalazła się u innej osoby. Wypowiedź Ulpiana ma charakter bardzo ogólny bez odniesienia do żadnego konkretnego stanu faktycznego i bez wskazania żadnej konkretnej figury condictio. Jurysta nie charakteryzuje też bliżej jakie przesłanki decydują o tym, że dana osoba uzyskała korzyść nie ze słusznej przyczyny ani też nie podaje kiedy przyczyna okazuje się niesłuszna. Co prawda Ulpian posłużył się terminem „słuszna przyczyna” (iusta causa), a nie „niesłuszna przyczyna” (iniusta causa), jednakże przesłankę uzasadniającą żądanie zwrotu korzyści opisał poprzez zaprzeczenie możliwości przyjęcia, że korzyść trafiła do innej osoby ze słusznej przyczyny. Moim zdaniem pomiędzy „niesłuszna przyczyną”, a brakiem „słusznej przyczyny” zachodzi co prawda dość subtelna, ale jednak różnica mogąca mieć znaczenie prak-

32 J. SONDEL, op. cit., s.v. pervenio. 
tyczne. W obu przypadkach oceniana jest prawidłowość (słuszność) causa uzyskania korzyści, jednakże z nieco innych punktów widzenia. W przypadku „niesłusznej przyczyny” powód musi wykazać, że uzyskanie przez pozwanego korzyści było niesłuszne, w przypadku braku „słusznej przyczyny” w interesie pozwanego pozostaje wykazanie słusznej przyczyny, która uzasadnia zatrzymanie przez niego korzyści. Zapewne w zdecydowanej większości przypadków powód bez większych trudności wykaże, że przyczyna była niesłuszna albo pozwany wykaże, że była ona słuszna, niemniej w sprawach bardzo ocennych przyjęcie jednego albo drugiego kryterium może mieć znaczenie dla rozstrzygnięcia sporu.

Fragment ten nie zawiera też bliższych wskazówek co do tego, czy warunkiem zastosowania condictio jest przeniesienie własności przedmiotu korzyści majątkowej, czy też skargą tą można posłużyć się również wtedy kiedy osoba, do której korzyść trafiła nie nabyła jej własności. Użycie czasownika pervenire skłania jednak do szerszej interpretacji sposobu nabycia korzyści. $Z$ tego względu wypowiedź Ulpiana jest przywoływana jako dowód tezy, że w prawie klasycznym zastosowanie condictio było możliwe również w innych przypadkach niż nabycie korzyści majątkowej wskutek datio ${ }^{33}$.

\section{Causa wyrażająca motyw lub cel świadczenia}

Drugą pod względem znaczenia z rzymskich skarg z tytułu bezpodstawnego wzbogacenia, po condictio indebiti, była condictio ob rem dati, nazwana prawdopodobnie dopiero w prawie justyniańskim condictio causa data causa non secuta. W źródłach dotyczącej tej condictio termin causa łączy się z datio stając się częścią pojęcia datio $o b$ causam, które używane jest obok pojęcia datio ob rem. W literaturze to rozumienie causa łączone jest $\mathrm{z}$ celem świadczenia, a zatem z celem uzgodnionym przez świadczącego i przyjmującego świadczenie, ze względu na który następuje świadczenie, ewentualnie z ocze-

33 A. SAcCoccio, op. cit., s. 178 i n. 
kiwanym stanem rzeczy, ze względu na który następuje świadczenie ${ }^{34}$. Jeżeli cel ten nie został osiagnnięty lub stan rzeczy nie zaszedł, świadczący ma prawo żądać zwrotu świadczenia.

Analiza źródeł wskazuje jednak na to, że takie rozumienie causa stanowi spore uproszczenie. Przekonuje o tym fragment 27 księgi komentarza żyjącego w II w. n.e. Pomponiusa do dzieł jednego z największych jurystów republikańskich Quintusa Muciusa Scaevoli ${ }^{35}$ :

D. 12,6,52 (Pomp. 5 ad Quint. Muc.): Damus aut ob causam aut ob rem: ob causam preateritam, veluti cum ideo do, quod aliquid a te consecutus sum vel quia aliquid a te factum est, ut, etiamsi falsa causa sit, repetitio eius pecuniae non sit: ob rem vero datur, ut aliquid sequatur, quo non sequente repetio competit.

Jurysta stwierdza, że dajemy (dare) coś albo ze względu na podstawę (ob causam) albo ze względu na cel (ob rem). Ze względu na podstawę odnoszącą się do przeszłości (causa preaterita), na przykład wtedy kiedy świadczący daje coś, ponieważ otrzymał coś od przyjmującego lub coś zostało dla niego przez przyjmującego uczynione, nawet jeśli podstawa ta (causa) okaże się fałszywa nie można żądać zwrotu pieniędzy. Z kolei w określonym celu ( ob rem) dajemy po to, aby coś nastąpiło (ut aliquid sequatur), jeżeli zaś to nie nastąpi przysługuje żądanie zwrotu świadczenia.

34 Tak jest w szczególności w ujęciu podręcznikowym, zob. np. M. J. GARCiA Garrido, Diritto privato romano, ed. italiana, red. M. BAlzarini, Torino 1992, S. 300; H. Honsell, Römisches Recht, Berlin-Heidelberg-New York 2002, s. 162; M. KurYŁowicz, A. WiLIŃski, Rzymskie prawo prywatne. Zarys wykładu, Zakamycze 1999, s. 296; W. LiTEWsKi, Słownik encyklopedyczny prawa rzymskiego, Kraków 1998 , s. v. condictio causa data causa non secuta; M. KASER, R. KNÜTEL, Römisches Privatrecht, München 2003, s. 307; W. Dajczak, [w:] W. DajczaK, T. Giaro, F. LongChamps De Beriér, Prawo rzymskie. U podstaw prawa prywatnego, Warszawa 2009, s. 522.

35 Ze względu na ograniczone ramy niniejszego opracowania nie podejmuję problemu komu należy przypisać autorstwo fragmentu: komentarzowi (Pomponius), czy juryście komentowanemu (Q. M. Scaevola). 
Pomponius wyraźnie przeciwstawia sobie datio ob causam i datio ob rem, zatem pojęcia te nie są równoznaczne, w związku z czym konstatacja, że świadczenie następuje w określonym celu okazuje się zbyt ogólna, aby uchwycić różnicę między obiema postaciami dationes. Tym samym niesatysfakcjonujące wydaje się odniesienie causa do celu świadczenia. Pojęcie celu świadczenia jest zbyt ogólne również z tego powodu, że każde świadczenie następuje w określonym celu, w najbardziej typowym przypadku dłużnik wykonujący zobowiązanie także świadczy celowo - w celu umorzenia zobowiązania. Tak szerokie rozumienie celu można więc z powodzeniem odnieść do innych condictiones ${ }^{36}$.

Z fragmentu wyraźnie wynika, że datio ob causam odnosi się do przeszłości (ob causam praeteritam), ściślej, ma miejsce z uwagi na to, że świadczący otrzymał coś uprzednio od odbiorcy świadczenia lub ten coś uczynił dla świadczącego, a zatem ze względu na uprzednie dare lub facere odbiorcy świadczenia. $Z$ kolei datio ob rem odnosi się do przyszłości, ma miejsce, aby coś nastapiło w przyszłości ${ }^{37}$. Nie można żądać zwrotu tego, co dano ob causam, nawet jeśli falsa causa sit, a zatem przekonanie świadczącego odnoszące się do uprzedniego zachowania się odbiorcy świadczenia okazało się błędne. Causa odnosi się tu do motywacji, którą kierował się świadczący, zaś u źródeł tej motywacji tkwi wyobrażenie świadczącego o pewnym zachowaniu przyjmującego świadczenie, które miało miejsce w przeszłości.

Znacznie obszerniejszej wypowiedzi na temat różnych celów datio Paulus udziela w siedemnastej księdze komentarza do dzieł Plautiusa:

D. 12,6,65 pr. (Paul. 17 ad Plaut.): In summa, ut generaliter de repetitione tractemus, sciendum est dari aut ob transactionem aut ob causam aut propter condicionem aut ob rem aut indebitum: in quibus omnibus quaeritur de repetitione.

Paulus odnosząc się w ogólny sposób (generaliter) do problematyki zwrotu świadczenia (repetitio) wymienia różne cele datio, stwierdziw-

${ }^{36} \mathrm{~W}$ ten sposób właśnie uczynił F. Schwarz, op. cit., passim.

37 S. E. Wunner, op. cit., s. 470; A. SAccoccio, op. cit., s. 223; J. D. Harke, Das klassische römische Kondiktionensystem..., s. 54. 
szy że daje się ze względu na zawartą ugodę (ob transactionem) lub z uwagi na podstawę ( ob causam) lub ze względu na zastrzeżony warunek (propter condicionem) lub cel (ob rem) albo daje się nienależnie (indebitum), a w każdym z tych przypadków powstaje problem zwrotu świadczenia. W dalszej treści fragmentu jurysta charakteryzuje każdą z poszczególnych postaci dationes, w tym datio ob causam:

D. 12,6,65,2 (Paul. 17 ad Plaut.): Id quoque, quod ob causam datur, puta quod negotia mea adiuta ab eo putavi, licet non sit factum, quia donari volui, quamvis falso mihi persuaserim, repeti non posse.

Według słów jurysty datio ob causam ma miejsce w sytuacji, w której dający działa w przekonaniu, że przyjmujący świadczenie prowadził jego sprawy. Jeżeli w rzeczywistości przyjmujący świadczenie nie prowadził spraw świadczącego, to świadczący nie może żądać zwrotu tego, co dał, ponieważ miał wolę dokonania darowizny, choćby działał w błędnym przekonaniu. Ponownie causa odnosi się do zdarzenia przeszłego, a nie do przyszłości, bowiem świadczący chce wynagrodzić to, że przyjmujaccy świadczenie prowadził jego sprawy i ta motywacja stanowi przyczynę sprawczą świadczenia. Causa stanowi tu zatem motyw świadczenia, a nie jego cel $^{38}$. Jeżeli przekonanie to okazuje się fałszywe, to świadczący nie może żądać zwrotu świadczenia, ponieważ w chwili, w której je spełniał działał z wolą dokonania darowizny. Przy tej interpretacji uwydatnia się różnica między celem i motywem świadczenia, albowiem celem świadczenia było dokonanie darowizny, zaś motywem przekonanie o zachowaniu osoby przyjmującej świadczenie w przyszłości. Właśnie w woli dokonania darowizny upatruje się głównego motywu rozstrzygnięcia ${ }^{39}$. Warto też zauważyć,

38 F. SCHWARZ, op. cit., s. 146.

39 L. Pellecchi, op. cit., s. 138 i n. Zdaniem A. SAccoccio, op. cit., s. 227, już sam fakt, że datio odnosiła się do zdarzenia przeszłego wyłączał możliwość posłużenia się condictio, odniesienie do causa donandi ma znaczenie w sytuacjach nadzwyczajnych. 
że rozstrzygnięcie to potwierdza ogólną zasadę, że błąd co do motywu świadczenia nie jest prawnie relewantny ${ }^{40}$.

Dookreślenie causa przymiotnikiem preaterita we fragmencie D. 12,6,52 i przykład podany przez Paulusa we fragmencie D. 12,6,65,2 pozwalają postawić pytanie, czy oprócz causa odnoszącej się do przeszłości terminem tym posługiwano się w odniesieniu do zdarzeń teraźniejszych lub przyszłych, a w konsekwencji czy pojęcie causa uzyskiwało również znaczenie celu świadczenia. Analiza źródeł, w których został użyty termin causa wskazuje na to, że obraz wynikający ze źródeł jest dalece bardziej skomplikowany niż przyjęcie, że causa oznacza motyw świadczącego, odnoszący się do zdarzenia przeszłego, a res oznacza cel świadczącego odnoszący się do przyszłości.

Inaczej niż Paulus pojęcie causa rozumiał Ulpian.

D. 12,4,1 pr. (Ulp. 26 ad ed.): Si ob rem non inhonestam data sit pecunia, ut filius emanciparetur vel servus manumitteretur vel a lite discedatur, causa secuta repetitio cessat.

Jurysta stwierdza, że jeżeli dano pieniądze nie w celu niemoralnym (res inhonesta), np. aby syn został wyzwolony spod władzy ojcowskiej lub niewolnik został wyzwolony lub aby odstapiono od prowadzenia procesu, jeżeli cel ten (causa) zostanie osiagnięty ustaje prawo żądania zwrotu.

Termin causa wydaje się bliskoznaczny terminowi res, wręcz został użyty wymiennie. Causa nie odnosi się tu do zdarzenia przeszłego, lecz do zdarzenia przyszłego, którego przykładem jest emancypacja syna lub wyzwolenie niewolnika.

Na takie znaczenie causa wskazują też inne fragmenty dzieł Ulpiana. Jurysta ten posługiwał się zwrotem causa non secuta w odniesieniu do świadczenia spełnionego tytułem posagu (dotis datio) na poczet małżeństwa, które później nie zostało zawarte ${ }^{41}$. Sformułowanie causa non secuta oznacza tu zatem przesłankę, ze względu na którą zostało spełnione świadczenie, a która nie ziściła się, ponieważ małżeństwo nie zo-

${ }^{40}$ F. SCHWARZ, op. cit., s. 146.

41 D. 12,2,4 (Ulp. 3 disput.). 
stało w ostateczności zawarte. W analogicznej sytuacji Paulus posłużył się sformułowaniem quasi ob rem datur et re non secuta ${ }^{42}$. W przypadku świadczenia tytułem posagu przed zawarciem małżeństwa causa odnosi się niewątpliwie do oczekiwanej okoliczności przyszłej, jaką jest zawarcie małżeństwa, a nie okoliczności przeszłej, samo świadczenie nie wynika zaś z woli dokonania darowizny. Znaczenie causa jest zatem inne niż w analizowanych fragmentach dzieł Pomponiusa i Paulusa. Powstaje jednak pytanie czy tak rozumianą causa należy odnieść do celu świadczenia. Wydaje się, że zawarcia małżeństwa nie należy traktować jako celu, ze względu na który nastapiło wydanie posagu lub, inaczej mówiąc, trudno twierdzić, że wydanie posagu miało bezpośrednio na celu zawarcie małżeństwa. Tym bardziej nie można zawarcia małżeństwa traktować jako świadczenie wzajemne w zamian za ustanowienie posagu. Bezpośrednim celem świadczenia jest tu przysporzenie posagu, a nie zawarcie małżeństwa. Cel ten jest jednak niewątpliwie związany z zawarciem małżeństwa, ponieważ świadczenie tytułem posagu następuje ze względu na oczekiwane zawarcie małżeństwa. Causa odniesiona jest jednak nie do ustanowienia posagu i tym samym nie do celu świadczenia, lecz do zawarcia małżeństwa, a zatem do okoliczności ze względu na którą następuje świadczenie, ale która nie jest jego celem.

Termin causa w rozstrzygnięciach Ulpiana ani nie jest odnoszony do przeszłości ani nie wskazuje na wolę dokonania darowizny, nie stanowi też motywu świadczenia. Ulpian posługuje się zatem zwrotem datio ob causam w innym znaczeniu niż czynili to Pomponius i Paulus. Koncepcji zarysowanej w analizowanych fragmentach dzieł Pomponiusa i Paulusa nie przejęto także w prawie poklasycznym, albowiem w konstytucjach cesarskich cesarzy Dioklecjana i Maksymiana nie pojawia się termin datio ob rem, lecz wyłącznie datio ob causam ${ }^{43}$. W ten sposób termin causa wyparł znany prawu klasycznemu termin res przejmując jego znaczenie.

\footnotetext{
${ }^{42}$ D. 12,4,9 (Paul. 17 ad Plaut.).

${ }^{43}$ C. $4,6,5$; C. $4,6,6$; C. $4,6,9$, C. $4,6,10$.
} 
Obraz wynikający ze źródeł prawa rzymskiego dotyczący istnienia dystynkcji między datio ob rem i datio ob causam nie jest jednoznaczny, czego skutkiem jest różnorodność poglądów wyrażonych na ten temat w literaturze. Zwolennicy poglądu przeciwstawiającego sobie oba pojęcia odnoszą res do oczekiwanego świadczenia wzajemnego ${ }^{44}$, natomiast causa do woli dokonania darowizny ${ }^{45}$ bądź też do celu, którego realizacja nie zależy od woli przyjmującego świadczenie i który nie był wiązany z darowizną ${ }^{46}$. Prezentowany jest też pogląd, że kluczowe dla odróżnienia obu postaci dationes jest odniesienie czasowe, datio ob causam podyktowana jest zdarzeniem przeszłym, datio ob rem następuje ze względu na zdarzenie przyszłe, w szczególności świadczenie wzajemne ${ }^{47}$. Znaczna część doktryny opowiada się za wymiennym stosowaniem ob rem i ob causam jako pojęć synonimicznych, co najwyżej jedynej różnicy dopatruje się w rozstrzygnięciach Paulusa ${ }^{48}$.

Szczególną postacią świadczenia jest świadczenie w celu niegodziwym, którego odzyskaniu służyła condictio ob turpem vel iniustam causam uważana za podkategorię condictio ob rem dati ${ }^{49}$. Nie dziwi

${ }^{44}$ F. Schwarz, op. cit., s. 117 i n. Zdaniem J.D. HARKe, Das klassische römische Kondiktionensystem, cit., s. 60, prototypem datio ob rem jest świadczenie spełnione w oczekiwaniu świadczenia wzajemnego, jednakże już w prawie klasycznym ta postać datio obejmowała również inne sytuacje. Stanowczo przeciwko zawężeniu datio ob rem do świadczenia wzajemnego opowiedział się ostatnio L. Pellecchi, op. cit., s. 140.

45 F. Schwarz, op. cit., s. 121.

46 F. Chaudet, 'Condictio causa data causa non secuta', Lausanne 1973, s. 89 i n.

47 J. D. Harke, Das klassische römische Kondiktionensystem..., s. 61; TenżE, Römisches Recht..., s. 187 i n.

48 S. E. Wunner, op. cit., s. 470; F. Chaudet, op. cit., s. 117; A. Guarino, Diritto privato romano, Napoli 1988, s. 840; R. Zimmermann, The Law of Obligations. Roman Foundations and the Civilian Tradition, Cape Town-Wetton- Johannesburg, s. 842 i n.; C.A. Cannata, op. cit., s. 94 i n.

49 Tak F. Schwarz, op. cit., s. 119; B. Kupisch, op. cit., s. 8; H. Honsell, Die Rückabwicklung sittenwidriger oder verbotener Geschäfte, München 1974, s. 54; TenżE, Römisches Recht, Berlin-Heidelberg-New York 2002, s. 163; R. Zimmermann, op. cit., s. 845, J.D. HARKE, Das klassische römische Kondiktionensystem..., s. 55. 
zatem fakt, że w źródłach dotyczącej tej figury condictio termin causa rozumiany jest podobnie ${ }^{50}$.

5. Causa odnosząca się do podstawy przyrzeczenia świadczenia

Użycie terminu causa w źródłach odnoszących się do bezpodstawnego wzbogacenia nie ogranicza się do sytuacji, w których określona rzecz lub pieniądz znalazły się u innej osoby czy to wskutek świadczenia, czy też w inny sposób. W innym kontekście terminem tym posługuje się Ulpian w 43 księdze komentarza do dzieł Sabinusa:

D. 12,7,1 pr. (Ulp. 43 ad Sab.): Est et haec species condictionis, si quis sine causa promiserit vel si solverit quis indebitum. qui autem promisit sine causa, condicere quantitatem non potest quam non dedit, sed ipsam obligationem.

Ulpian wyróżnia tu tę postać condictio, którą stosuje się kiedy ktoś przyrzekł bez podstawy (sine causa) lub spełnił świadczenie, którego nie miał obowiązku spełniać (indebitum). Kto przyrzekł bez podstawy nie może żądać zwrotu żadnej kwoty pieniężnej, ponieważ jej nie świadczył, lecz może żądać uznania go wolnym od zobowiązania.

W tym przypadku causa nie odnosi się do żadnego przesunięcia majątkowego, czy to będącego skutkiem świadczenia, czy też takiego, które nastąpiło w inny sposób, czy to polegającego na przeniesieniu własności lub posiadania rzeczy. Żadna korzyść majątkowa przynależna jednej osobie nie znalazła się u innej osoby, nie ma więc niczego, co by mogło stać się substratem zwrotu. Tym razem causa odnosi się do samej obligatio wynikającej z przyrzeczenia, zatem do zaciąnnięcia obowiązku świadczenia. Przyrzeczenie to odnosi się do kontraktu stypulacji ${ }^{51}$. Jeżeli ktoś przyrzekł bez przyczyny i jeszcze zobowiązania swego nie wykonał, może żądać jedynie uwolnienia go z obowiązku

\footnotetext{
50 Zob. D. 12,5,1,2 (Paul. 10 ad Sab.).

${ }^{51}$ Por. J.G. Wolf, op. cit., s. 32 i n.; L. Vacca, op. cit., s. 27; C.A. Cannata, op. cit., s. 94.
} 
świadczenia ${ }^{52}$. Fragment ten stanowi podstawę źródłową tzw. condictio liberationis, skargi służącej uzyskaniu zwolnienia $\mathrm{z}$ długu ${ }^{53}$.

Jurysta poprzestaje na ogólnym stwierdzeniu braku causa przyrzeczenia, nie odnosi się zaś do problemu prawidłowości causa.

W dalszej części fragmentu w brzmieniu, jakie zachowało się w Digestach, Ulpian pisze:

D. 12,7,1,1 (Ulp. 43 ad Sab.): Sed et si ob causam promisit, causa tamen secuta non est, dicendum est condictionem locum habere.

Jeżeli ktoś złożył przyrzeczenie ze względu na określony cel, który nie został osiagnięty, zastosowanie znajduje condictio. Causa odnosi się do celu przyrzeczenia, a nie do celu świadczenia, gdyż takie jeszcze nie nastąpiło, co wyróżnia opisaną sytuację od świadczeń (dationes) spełnianych w określonym celu.

W tym samym znaczeniu Ulpian posłużył się terminem causa w następnym fragmencie:

D. 12,7,1,2 (Ulp. 43 ad Sab.): Sive ab initio sine causa promissum est, sive fuit causa promittendi quae finita est vel secuta non est, dicendum est condictioni locum fore.

Condictio znajduje zastosowanie niezależnie od tego, czy złożono przyrzeczenie bez podstawy (sine causa), czy istniejąca podstawa przyrzeczenia później odpadła (causa finita) lub też nie został osiągnięty cel przyrzeczenia (causa non secuta) ${ }^{54}$. W tym krótkim zdaniu termin causa został użyty w odmiennych znaczeniach jako podstawa uzasadniająca przyrzeczenie i jako cel, ze względu na który następuje przyrzeczenie. Tak rozumiana causa bądź to od początku nie zacho-

52 Por. C.A. Cannata, op. cit., s. 94.

53 F. Schwarz, op. cit., s. 48; J. G. Wolf, op. cit., s. 51; B. Kupisch, op. cit., s. 3; L. VACCA, op. cit., s. 27; A. SACCOCCIO, op. cit., s. 526 i n.; C.A. CANnATA, op. cit., s. 95.

54 J.G. Wolf, op. cit., s. 33, stwierdza, że w każdym z tych przypadków podstawą condictio jest brak causa . 
dziła $^{55}$, bądź zachodziła tylko do określonego momentu (causa finita), bądź też wyznaczała cel świadczenia, którego weryfikacja następowała w określonym momencie w przyszłości ${ }^{56}$. Opisany trójpodział odniesiony został do przyrzeczenia świadczenia, nie mniej przedstawia się on analogicznie do podziału poszczególnych figur condictiones stosowanych w celu zwrotu już spełnionego świadczenia (odpowiednio: condictio indebiti, condictio ob causam finitam, condictio causa data causa non secuta). Z tego względu podzielam tezę, że trójpodział ten mógł mieć znaczenie w kształtowaniu się poszczególnych figur condictiones, ponieważ każdy z elementów tego podziału można przypisać do konkretnej figury condictio ${ }^{57}$. Znaczenia terminu causa we wszystkich przypadkach, w których został on odniesiony do stypulacyjnego przyrzeczenia świadczenia odpowiadają tym znaczeniom, jakie termin ten uzyskał w sytuacjach, w których świadczenie zostało już spełnione. Innymi słowy wydaje się, że te same znaczenia causa odnoszono do przyrzeczenia świadczenia, jak i do świadczenia, które zostało już spełnione. Inny jest jedynie kontekst sytuacyjny, w którym termin ten został użyty w zależności od tego, czy świadczenie zostało spełnione czy dopiero ma ostać spełnione.

6. Causa uzasadniająca zatrzymanie korzyści majątkowej

Gaius wskazuje na jeszcze jedno znaczenie causa:

D. 24,1,6 (Gai. 11 ad ed. prov.): Quia quod ex non concessa donatione retinetur, id aut sine causa aut ex iniusta causa retineri intellegitur: ex quibus causis condictio nasci solet.

55 Ulpian odnosi się tu do sytuacji, w której przyrzeczono świadczenie nienależne indebitum promittere (F. Schwarz, op. cit., s. 204; J. G. Wolf, op. cit., s. 44 i n.).

${ }^{56}$ Por. J. G. Wolf, op. cit., s. 32 i n.; J. D. Harke, Das klassische römische Kondiktionensystem..., s. 66.

${ }^{57}$ Zdaniem J.G. Wolf, op. cit., s. 38 i n., poklasyczna wschodniorzymska jurysprudencja uporządkowała poszczególne przypadki zastosowania condictio (Kondiktionensfälle) według tego, czy causa brakowało od samego początku, czy oczekiwana causa się nie urzeczywistniła lub istniejąca causa odpadła. 
Fragment ten dotyczy zabronionych w prawie rzymskim darowizn między małżonkami. Gaius stwierdza w nim, że ponieważ korzyść majątkowa zatrzymana jest (retinere) z niedozwolonej darowizny, uważa się, że zatrzymana jest bez podstawy lub z uwagi na niesłuszną podstawę, a w takich przypadkach zastosowanie znajduje condictio. Gaius posłużył się terminem causa jako podstawy zatrzymania korzyści majątkowej, która to podstawa w tym przypadku nie istnieje lub jest niesłuszna. Fragment ten wskazywany jest jako podstawa źródłowa opisanej niżej teorii, że w prawie rzymskim condictio była stosowana w tych przypadkach, w których pozwany nie mógł wykazać prawidłowej podstawy zatrzymania korzyści majątkowej (causa retinendi). Można by powiedzieć, że to rozumienie causa w zasadzie pokrywa się z pierwszym z wyróżnionych przeze mnie jej znaczeń, albowiem tu także określa stan, w którym pewne dobro majątkowe znajduje się $\mathrm{u}$ innej osoby. Istotne znaczenie ma jednak użycie czasownika retinere i odniesienie causa do prawa zatrzymania korzyści majątkowej. Ta, wydawałaby się dość subtelna, różnica wystarcza jednak, aby w oparciu m.in. o analizowany fragment budować koncepcję causa retinendi. Okoliczność ta potwierdza, że nawet subtelne odcienie znaczeniowe causa mogą okazać się doniosłe w procesie interpretacji źródeł prawa rzymskiego i formułowania teorii dotyczącej rzymskiej koncepcji bezpodstawnego wzbogacenia.

\section{WNIOSKI}

Analiza znaczenia i kontekstu sytuacyjnego użycia terminu causa w źródłach dotyczących bezpodstawnego wzbogacenia wskazuje na to, że nawet w tym obszarze prawnym termin ten nie jest jednoznaczny. Da się wyróżnić kilka znaczeń causa, pomiędzy którymi zachodzą subtelne różnice. To samo znaczenie causa było też stosowane w różnych kontekstach sytuacyjnych. Powstaje pytanie jakie ma to znaczenie dla badań nad rzymską koncepcją bezpodstawnego wzbogacenia, pomijając oczywisty wniosek, że pewną wartością samą w sobie jest ustalenie znaczeń causa w poszczególnych fragmentach źródłowych. Otóż w moim przekonaniu powyższe wnioski można skonfron- 
tować $\mathrm{z}$ proponowanymi aktualnie w romanistyce poglądami na temat poszczególnych zagadnień bezpodstawnego wzbogacenia. Ze względu na ograniczone ramy opracowania poprzestanę na kilku przykładach.

Jednym z zagadnień szeroko dyskutowanych w nauce jest problem istnienia w prawie rzymskim tzw. causa condictionis, tj. wspólnej wszystkim condictiones podstawie uzasadniającej roszczenie, czy też wspólnego wyobrażenia przesłanek zobowiązań $\mathrm{z}$ tego tytułu ${ }^{58}$. Powstaje pytanie czy już samo postawienie tego problemu jest uzasadnione treścią dyskursu jurystów, czy też jest to pytanie nurtujące współczesnego nam prawnika, który odnosi do prawa rzymskiego zagadnienia frapujące współczesnego cywilistę, poszukując odpowiedzi na pytania w istocie ,nierzymskie”. Uważam, że w żadnym ze znaczeń wskazanych w analizowanych źródłach causa nie jest tak rozumiana jak w powyższym pytaniu o causa condictionis. Sam termin causa condictionis co prawda kilkukrotnie pojawia się w źródłach, choć akurat bez odniesienia do analizowanych przeze mnie condictiones ${ }^{59}$, w żadnym jednak $\mathrm{z}$ tych źródeł termin ten nie został użyty w abstrakcyjnym znaczeniu, o którym mowa powyżej ${ }^{60}$. Wydaje się zatem, że problem istnienia causa condictionis nie był przynajmniej wprost stawiany przez samych Rzymian, co oczywiście nie stoi na przeszkodzie, aby postawił go współczesny romanista, poszukując odpowiedzi użytecznych dla współczesnej cywilistyki.

Aktualnie najpopularniejszy w nauce pogląd na temat causa condictionis odnosi się do koncepcji causa przysporzenia majątkowego i opiera się na rozróżnieniu między causa dandi, rozumianej szero-

${ }^{58} \mathrm{Na}$ ten temat zob. A. EHRHARDT, 'Iusta causa traditionis'. Eine Untersuchung über den Erwerb des Eigentums nach römischem Recht, Berlin-Leipzig 1930, s. 42 i s. 48; F. Schwarz, op. cit., s. 229, s. 303; A. Simonius, Zur Frage einer einheitlichen 'causa condictionis', [w:] Festschrift Hans Lewald, Basel 1953, p. 161; S. HäHNCHEN, op. cit., s. 13, s. 18 i n.; W. DAJCZAK, Tradycja romanistyczna a wspótczesna debata o zasadach prawa prywatnego. Uwagi na tle problemu niestusznego wzbogacenia, [w:] Prawo rzymskie a kultura prawna Europy, red. A. DĘBIński i M. JońcA, Lublin 2008, s. 132 i n.

${ }_{59}$ D. 12,2,28.9 (Paul. 18 ad ed.), D. 19,1,30 pr. (Afric. 8 quaest.), D. 45,1,29,1 (Ulp. 46 ad Sab.), D. 46,3,94,2 (Pap. 8 quaest.), D. 46,3,96,4 (Pap. 11 resp.).

${ }^{60}$ S. HÄHNCHEN, op. cit., s. 19. 
ko jako przyczyna sprawcza świadczenia i causa retinendi rozumianej jako przyczyna uzasadniająca zatrzymanie otrzymanego uprzednio świadczenia ${ }^{61}$. W tym ujęciu roszczenie o zwrot świadczenia opiera się na tym, że nie zachodzi prawidłowa podstawa uzasadniająca zatrzymanie świadczenia przez wzbogaconego ${ }^{62}$. Jedynie jednak ostatnie z analizowanych źródeł (D. 24,1,6) wprost nawiązuje do podstawy zatrzymania korzyści majątkowej, jedynie w tym źródle rozumienie causa można odnieść do causa retinendi. Natomiast pozostałe źródła mogą uzasadniać tę koncepcję i to rozumienie causa tylko przy ich odpowiedniej interpretacji, nietrudno bowiem stwierdzić, że jeżeli korzyść majątkowa znajduje się u innej osoby z niesłusznej przyczyny lub jeżeli cel świadczenia nie został osiagnięty, to osoba ta nie ma prawa jej zatrzymania. Wniosek taki wynika jednak z interpretacji źródeł w kontekście koncepcji causa retinendi, a nie tyle z treści samym źródeł. Podstawową zaś wadą tej koncepcji jest nie tyle to, że wynika ona w większym stopniu z interpretacji niż treści samych źródeł, lecz to, że można ją odnieść z powodzeniem do każdego roszczenia o wydanie rzeczy bez względu na jego podstawę prawną, zwykle bowiem perspektywę oceny odnosi się do tego, czy zachodzi podstawa zatrzymania tej rzeczy ${ }^{63}$.

Analizowane źródła nie wspierają też teorii, że datio sine causa była centralnym pojęciem rzymskiej doktryny bezpodstawnego wzbogacenia $^{64}$. Pogląd ten budzi o tyle zastrzeżenia, że nie można założyć, że w każdym z analizowanych źródeł wzbogacenie nastapiło wskutek

${ }^{61} \mathrm{Na}$ temat causa dandi i causa retinendi zob. F. Schwarz, op. cit., s. 224 i n.

${ }^{62}$ E. RABEL, Grundzüge des römischen Privatrecht, [w:] Enzyklopädie der Rechtswissenschaft, I, Berlin 1915, s. 399 i n.; F. SchwARZ, op. cit., s. 210 i n.; A. Simonius, op. cit., s. 165 i n.; A. WACKE, 'Actio rerum amotarum', Köln 1963, s. 110; A. D'ors, 'Creditum', «RE» Suppl. 10/1965, szp. 1158; J.G. Wolf, op. cit., s. 33 przyp. 1; A. Watson, Roman Private Law around 200 BC, Edinburgh 1971, s. 125; G. Astuti, Azioni di aricchimento (Premessa storica), «Tradizione romanistica e civiltà europea» 3/1984, s. 1786 i n.; Th. MaYer- Maly, Römisches Privatrecht, Wien 1999, s. 155.

${ }^{63}$ Szerzej do tej koncepcji odniosłem się w pracy pt. The problem of 'causa condictionis'..., s. 29-42.

${ }^{64}$ Tak L. VACCA, op. cit., passim; J. D. HARKE, Das klassische römische Kondiktionensystem..., s. 62 i n. 
datio, przeciwnie treść fragmentów zdaje się przemawiać za tym, że datio nie była konieczna. Trudno także odnieść datio sine causa do rozumienia causa jako motywu lub celu świadczenia. Poza tym w analizowanych źródłach oprócz sformułowania sine causa posługiwano się zwrotem ex iniusta causa.

\section{The Concept of 'Causa' in the Sources of Roman LaW Related to Unjustified ENRICHMENT}

\section{Summary}

In this paper I analyze the meaning of causa in the sources of Roman law in fourth, fifth, sixth and seventh title of the twelfth book of Digest's. The aim of my study is to participate in the contemporary discussion on several crucial issues of Roman conception of unjustified enrichment. In my opinion research into the concept of causa can contribute to the better evaluation of the theories on causa condictionis, causa dandi, causa retinendi, the theory that datio sine causa was the central concept of Roman unjustified enrichment, as well as the theory that datio was a basic precondition of the application of condictio.

I come to a general conclusion that causa had several different meanings: a) causa as an qualification of the fact that a benefit is in the hands of another person;

b) causa which related to the legal basis of acquisition of a benefit;

c) causa which related to the way in which a benefit was acquired;

d) causa as a motive or an objective of the performance;

e) causa which related to the basis of a promise of performance;

f) causa which justified the retention of a benefit.

Neither of the abovementioned meanings of causa corresponds to the causa condictionis understood in the abstract way as a ground for claims common to all condictiones, a common idea of the remedy for the recovery of an unjust enrichment. Only the last meaning related to the conception of causa retinendi. The theory that datio sine causa was the central concept of Roman does not seems to be justified. 